\title{
PENGEMBANGAN MODEL PROJECT BASED LEARNING DALAM PEMBELAJARAN TEMATIK MENGGUNAKAN PENDEKATAN SAINTIFIK UNTUK MENGEMBANGKAN SIKAP PEDULI LINGKUNGAN DAN KREATIVITAS BAGI SISWA SD
}

\author{
V Karjiyati, Neza Agusdianita \\ Program Studi PGSD FKIP Universitas Bengkulu \\ vkarjiyati@gmail.com, neza.agudianita@gmail.com
}

\begin{abstract}
Abstrak
Tujuan penelitian ini adalah mengembangkan model Project Based Learning (PjBL) dalam pembelajaran tematik menggunakan pendekatan saintifik untuk mengembangkan sikap peduli lingkungan dan kreativitas bagi siswa SD. Metode penelitian yang digunakan dalam penelitian ini adalah penelitian pengembangan. Hasil penelitian yang telah dicapai adalah: (1) pemetaan tema dan subtema kelas IV dan kelas V, (2) perangkat pembelajaran tematik dengan model Project Based Learning (PjBL) menggunakan pendekatan saintifik pada kelas IV dan Kelas V SD dan (3) instrumen penilaian otentik untuk menilai sikap peduli lingkungan dan kreativitas.
\end{abstract}

Kata Kunci: Model PjBL, Pembelajaran Tematik, Pendekatan Saintifik, Sikap Peduli lingkungan dan Kreativitas.

\section{PENDAHULUAN}

Kerusakan lingkungan yang ditandai dengan pemananasan global, berbagai macam polusi, peristiwa banjir, dan tanah longsor semakin memprihatinkan. Upaya penanganan melalui berbagai aspek sudah dilakukan, namun kenyataannya kondisi lingkungan masih membutuhkan penangan yang serius. Salah satu masalah lingkungan yang perlu mendapatkan perhatian yaitu menumpuknya sampah di manamana yang sangat menggangu kesehatan dan kenyamanan. Kesadaran masyarakat untuk menangani masalah sampah masih rendah. Padahal jika diolah sampah sebenarnya memiliki nilai ekonomis yang tinggi.

Penanganan masalah sampah dapat dilakukan melalui Pendidikan Lingkungan Hidup (PLH). Sejak usia dini,anak dilatih dan dibiasakan untuk membuang sampah pada tempatnya. Melalui PLH, pembiasaan dan keteladanan diharapkan dapat menumbuhkan kesadaran dan kepedulian terhadap lingkungan.
Sesuai dengan pendapat Hamzah (2013) menyatakan pendidikan lingkungan tidak hanya memberikan pengetahuan tentang lingkungan tetapi juga meningkatkan kesadaran terhadap lingkungan dan kepeduliannya terhadap kondisi lingkungan.

Kenyataan di lapangan, di sekolah yang berada di Kota Bengkulu masih terlihat sampah berserakan di mana-mana. Siswa belum terbiasa untuk membuang sampah pada kotak sampah yang disediakan. Kebijakan pemerintah setiap sekolah minimal harus menyediakan dua kotak sampah organik dan anorganik. Sampah yang telah terpilah bisa dimanfaatkan sebagai bahan baku untuk membuat suatu karya. Sampah organik bisa dijadikan bahan baku pembuatan pupuk kompos. Sedangkan sampah anorganik bisa dijadikan bahan baku membuat karya seni kerajinan tangan. Melalui pembelajaran pembuatan karya tersebut, diharapkan dapat menumbuhkan kesadaran dan berkembangnya sikap peduli lingkungan. 
Kurikulum 2013 menggunakan pembelajaran tematik integratif dengan pendekatan saintifik. Pembelajaran tematik integratif yaitu pembelajaran terpadu yang menggunakan tema untuk mengaitkan beberapa mata pelajaran sehingga dapat memberikan pengalaman bermakna bagi siswa (Hardianti, 2015). Pengembangan sikap peduli lingkungan dan kreativitas dikemas dalam pembelajaran tematik dengan menggunakan model Project Based Learning (PjBL). Model PjBL dalam pembelajarannya berpusat pada siswa untuk menyelesaikan suatu proyek. Kelebihan dari model ini diantaranya:

mendorong siswa untuk mengembangkan dan mempraktikkan keterampilan berkomunikasi dan (2) melibatkan siswa untuk belajar mengambil informasi dan menunjukkan pengetahuan yang dimiliki kemudian diimplementasikan dengan dunia nyata (Thomas, 2000) Berdasarkan permasalahan di atas maka peneliti melakukan identifikasi terhadap tema, subtema, kompetensi dasar dan indikator yang memuat sikap peduli lingkungan.

\section{METODE PENELITIAN}

Jenis penelitian ini adalah pengembangan dan penelitian research and development $(R \& D)$ yang mencakup serangkaian kegiatan: (1) tahap pengembangan model; (2) validasi model oleh ahli; (3) revisi model berdasarkan hasil validasi; (4) uji coba model pada skala kecil; (5) revisi model berdasarkan hasil uji coba skala kecil; dan (6) penelitian eksperimen (Borg dan Gall, 1983).

Tahap pengembangan model pembelajaran ini, meliputi: (1) pemetaan tema dan kompetensi dasar kelas IV dan $\mathrm{V}$ yang memuat sikap lingkungan hidup dan kreativias; mengidentifikasi indikator per kompetensi dasar yang mengandung sikap peduli lingkungan dan kreativitas; (3) menyusun buram model pembelajaran yang terdiri atas: Rencana Pelaksanaan Pembelajaran, Lembar Kegiatan Siswa/LKS; dan (4) membuat instrumen evaluasi untuk penilaian sikap peduli lingkungan dan kreativitas untuk siswa kelas IV dan V SD.

\section{HASIL PENELITIAN}

\section{Pemetaan Tema dan Subtema untuk Kelas IV dan Kelas V}

Pelaksanaan kurikulum 2013 di SD dilaksanakan melalui pembelajaran tematik dengan mengintegrasikan berbagai Kompetensi Dasar dari berbagai mata pelajaran ke dalam suatu tema. Hasil analisis Kurikulum 2013 kelas IV dan kelas $\mathrm{V}$ terdapat sembilan tema yang setiap tema dikembangkan menjadi empat subtema. Setiap subtema dikembangkan menjadi enam pembelajaran.

Hasil pemetaan tema yang memuat sikap peduli lingkungan pada kelas IV yaitu : 1) Selalu Berhemat Energi, 2) Peduli terhadap lingkungan hidup, 3) Berbagai Pekerjaan, 4) Indahnya negeriku, dan 5) Tempat tinggalku. Setiap tema dikembangkan menjadi subtema, setiap subtema terdiri dari kompetensi dasar dari beberapa mata pelajaran dan setiap kompetensi dasar dikembangkan menjadi indikator.

Pada tema Selalu Berhemat Energi terdiri dua subtema, yaitu : 1) Macam-macam energi yang terdiri dari lima kompetensi dasar untuk mata pelajaran IPA, Bahasa Indonesia, IPS, PKn dan SBdP, 2) Pemanfaatan energi yang terdiri dari lima kompetensi dasar untuk mata pelajaran IPA, Bahasa Indonesia, IPS, PKn dan SBdP. Kompetensi dasar dari setiap mata pelajaran dikembangkan menjadi indikator-indikator yang memuat sikap peduli lingkungan.

Tema Peduli Terhadap Lingkungan Hidup terdiri dari dua subtema, yaitu : 1) Keberagaman makhluk hidup di lingkungan rumahku, yang terdiri dari lima kompetensi dasar untuk mata pelajaran IPA, Bahasa Indonesia, IPS, PKn dan SBdP, 2) Ayo cintai lingkungan, yang terdiri dari lima kompetensi dasar untuk mata pelajaran IPA, Bahasa Indonesia, IPS, PKn dan SBdP. Kompetensi dasar dari setiap mata pelajaran dikembangkan menjadi indikator-indikator yang memuat sikap peduli lingkungan. 
Tema Berbagai Pekerjaan terdiri dari tiga subtema, yaitu : 1) Jenis-jenis pekerjaan, yang terdiri dari lima kompetensi dasar untuk mata pelajaran IPA, Bahasa Indonesia, IPS, PKn dan SBdP, 2) Barang dan jasa, yang terdiri dari lima kompetensi dasar untuk mata pelajaran IPA, Bahasa Indonesia, IPS, PKn dan SBdP, 3) Pekerjaan orang tuaku, yang terdiri dari lima kompetensi dasar untuk mata pelajaran IPA, Bahasa Indonesia, IPS, PKn dan SBdP. Kompetensi dasar dari setiap mata pelajaran dikembangkan menjadi indikator-indikator yang memuat sikap peduli lingkungan.

Tema Indahnya Negeriku terdiri dari tiga subtema, yaitu : 1) Keanekaragaman hewan dan tumbuhan, yang terdiri dari lima kompetensi dasar untuk mata pelajaran IPA, Bahasa Indonesia, IPS, PKn dan SBdP, 2) Keindahan alam negeriku, yang terdiri dari lima kompetensi dasar untuk mata pelajaran IPA, Bahasa Indonesia, IPS, PKn dan SBdP, 3) Indahnya peninggalan sejarah, yang terdiri dari lima kompetensi dasar untuk mata pelajaran IPA, Bahasa Indonesia, IPS, PKn dan SBdP. Kompetensi dasar dari setiap mata pelajaran dikembangkan menjadi indikator-indikator yang memuat sikap peduli lingkungan.

Tema Tempat Tinggalku terdiri dari tiga subtema, yaitu : 1) Lingkungan Temapat Tinggalku, yang terdiri dari lima kompetensi dasar untuk mata pelajaran IPA, Bahasa Indonesia, IPS, PKn dan SBdP, 2) Keunikan daerah tempat tinggalku, yang terdiri dari lima kompetensi dasar untuk mata pelajaran IPA, Bahasa Indonesia, IPS, PKn dan SBdP, 3) Aku bangga dengan tempat tinggalku, yang terdiri dari lima kompetensi dasar untuk mata pelajaran IPA, Bahasa Indonesia, IPS, PKn dan SBdP. Kompetensi dasar dari setiap mata pelajaran dikembangkan menjadi indikator-indikator yang memuat sikap peduli lingkungan.

Selanjutnya hasil pemetaan tema yang memuat sikap peduli lingkungan pada kelas $\mathrm{V}$ terdiri empat tema, yaitu : 1) Benda-benda di Lingkungan Sekitar, 2) Peristiwa dalam Kehidupan, 3) Ekosistem, dan 4) Lingkungan
Sahabat Kita. Setiap tema dikembangkan menjadi subtema, setiap subtema terdiri dari kompetensi dasar dari beberapa mata pelajaran dan setiap kompetensi dasar dikembangkan menjadi indikator.

Pada tema Selalu Benda-benda di Lingkungan Sekitar terdiri satu subtema, yaitu Wujud benda dan cirinya yang terdiri dari lima kompetensi dasar untuk mata pelajaran IPA, Bahasa Indonesia, IPS, PKn dan SBdP. Kompetensi dasar dari setiap mata pelajaran dikembangkan menjadi indikator-indikator yang memuat sikap peduli lingkungan.

Pada tema Peristiwa dalam Kehidupan terdiri satu subtema, yaitu Macam-macam peristiwa dalam kehidupan yang terdiri dari lima kompetensi dasar untuk mata pelajaran IPA, Bahasa Indonesia, IPS, PKn dan SBdP. Kompetensi dasar dari setiap mata pelajaran dikembangkan menjadi indikator-indikator yang memuat sikap peduli lingkungan.

Pada tema Ekosistem terdiri dua subtema, yaitu : 1) Komponen ekosistem yang terdiri dari lima kompetensi dasar untuk mata pelajaran IPA, Bahasa Indonesia, IPS, PKn dan SBdP, 2) Hubungan makhluk hidup dalam ekosistem yang terdiri dari lima kompetensi dasar untuk mata pelajaran IPA, Bahasa Indonesia, IPS, PKn dan SBdP. Kompetensi dasar dari setiap mata pelajaran dikembangkan menjadi indikatorindikator yang memuat sikap peduli lingkungan.

Pada tema Lingkungan Sahabat Kita terdiri tiga subtema, yaitu : 1) Manusia dan lingkungan yang terdiri dari lima kompetensi dasar untuk mata pelajaran IPA, Bahasa Indonesia, IPS, PKn dan SBdP, 2) Perubahan lingkungan, yang terdiri dari lima kompetensi dasar untuk mata pelajaran IPA, Bahasa Indonesia, IPS, PKn dan SBdP dan 3) Pelestarian lingkungan yang terdiri dari lima kompetensi dasar untuk mata pelajaran IPA, Bahasa Indonesia, IPS, PKn dan SBdP. Kompetensi dasar dari setiap mata pelajaran dikembangkan menjadi indikator-indikator yang memuat sikap peduli lingkungan. 


\section{Perangkat Pembelajaran model Project Based Learning (PJBL) dalam pembelajaran tematik menggunakan pendekatan saintifik}

Peneliti telah mengembangkan perangkat pembelajaran model Project Based Learning (PjBL) dalam pembelajaran tematik menggunakan pendekatan saintifik bagi siswa SD pada kelas IV dan Kelas V. Adapun tema untuk yang digunakan untuk kelas IV adalah tema tiga yaitu Peduli Terhadap Makhuk Hidup. Subtemanya yaitu Ayo Cintai Lingkungan. Mata pelajaran yang dipakai yaitu mata pelajaran PKn, Bahasa Indonesia, IPA dan SBdP. Adapun kompetensi dasar yang digunakan disajikan pada tabel berikut.

Tabel 1. Pemetaan kompetensi dasar per mata pelajaran pada kelas IV

\begin{tabular}{|l|l|l|}
\hline No & \multicolumn{1}{|c|}{$\begin{array}{c}\text { Mata } \\
\text { Pelajaran }\end{array}$} & \multicolumn{1}{c|}{ Kompetensi Dasar } \\
\hline 1 & PKn & $\begin{array}{l}\text { 3.2 Memahami hak dan kewajiban sebagai warga dalam kehidupan sehari-hari di rumah, } \\
\text { sekolah, dan masyarakat. } \\
\text { 4.2 Mengamati dan menceritakan perilaku di sekitar rumah dan sekolah dari sudut pandang } \\
\text { simbol pancasila sebagai satu kesatuan yang utuh. }\end{array}$ \\
\hline 2 & $\begin{array}{l}\text { Bahasa } \\
\text { Indonesia }\end{array}$ & $\begin{array}{l}\text { 3.4 Menggali informasi dari teks cerita petualangan tentang sumber daya alam dengan bantuan } \\
\text { guru dan teman dalam bahasa Indonesia lisan dengan memilih dan memilah kosa kata baku } \\
\text { 4.4 Menyajikan teks cerita petualangan tentang lingkungan dan sumber daya alam secara } \\
\text { mandiri, dalam teks bahasa Indonesia lisan dan tulisan dengan memilih dan memilah kosa kata } \\
\text { baku }\end{array}$ \\
\hline 3 & IPA & $\begin{array}{l}\text { 3.7 Mendeskripsikan hubungan antara sumber daya alam dengan lingkungan, teknologi, dan } \\
\text { masyarakat } \\
4.6 \text { Menyajikan laporan tentang sumber daya alam dan pemanfaatannya oleh masyarakat }\end{array}$ \\
\hline 4 & SBdP & $\begin{array}{l}3.2 \text { Mengenal gambar alam benda, dan kolase } \\
4.2 \text { Membuat karya seni kolase dengan berbagai bahan. }\end{array}$ \\
\hline
\end{tabular}

Adapun tema untuk yang digunakan untuk kelas $\mathrm{V}$ adalah tema sembilan yaitu Lingkungan Sahabat Kita. Subtemanya yaitu Pelestarian Lingkungan. Mata pelajaran yang dipakai yaitu mata pelajaran PKn, Bahasa Indonesia, IPA dan SBdP. Adapun kompetensi dasar yang digunakan disajikan pada tabel 2.
Adapun tahapan kegiatan pembelajaran untuk model Project Based Learning (PjBL) dalam pembelajaran tematik menggunakan pendekatan saintifik disajikan pada tabel 3 .

Tabel 2. Pemetaan kompetensi dasar per mata pelajaran pada kelas $\mathrm{V}$

\begin{tabular}{|l|l|l|}
\hline No & \multicolumn{1}{|c|}{$\begin{array}{c}\text { Mata } \\
\text { Pelajaran }\end{array}$} & \multicolumn{1}{c|}{ Kompetensi Dasar } \\
\hline 1 & PKn & $\begin{array}{l}3.2 \text { Memahami hak kewajiban dan tanggung jawab sebagai warga dalam kehidupan sehari-hari } \\
\text { di rumah, dan sekolah } \\
4.2 \text { Melaksanakan kewajiban dan menegakkan aturan di lingkungan rumah, dan sekolah }\end{array}$ \\
\hline 2 & $\begin{array}{l}\text { Bahasa } \\
\text { Indonesia }\end{array}$ & $\begin{array}{l}\text { 3.1 Menggali informasi dari teks laporan buku tentang makanan dan rantai makanan, kesehatan } \\
\text { manusia, keseimbangan ekosistem, serta alam dan pengaruh kegiatan manusia dengan bantuan } \\
\text { guru dan teman dalam bahasa Indonesia lisan dan tulis dengan memilih dan memilah kosakata } \\
\text { baku } \\
4.1 \text { Mengamati, mengolah, dan menyajikan teks laporan buku tentang makanan dan rantai } \\
\text { makanan, kesehatan manusia, keseimbangan ekosistem, serta alam dan pengaruh kegiatan } \\
\text { manusia secara mandiri dalam bahasa Indonesia lisan dan tulis dengan memilih dan memilah } \\
\text { kosakata baku. }\end{array}$ \\
\hline 3 & IPA & $\begin{array}{l}\text { 3.4 Mengidentifikasi perubahan yang terjadi di alam, hubungannya dengan penggunaan sumber } \\
\text { daya alam, dan pengaruh kegiatan manusia terhadap keseimbangan lingkungan sekitar. } \\
4.7 \text { Menyajikan hasil laporan tentang permasalahan akibat terganggunya keseimbangan alam } \\
\text { akibat ulah manusia, serta memprediksi apa yang akan terjadi jika permasalahan tersebut tidak } \\
\text { diatasi }\end{array}$ \\
\hline 4 & SBdP & \begin{tabular}{l}
3.4 Memahami prosedur dan langkah kerja dalam berkarya kreatif berdasarkan ciri khas daerah \\
\hline
\end{tabular} \\
\hline
\end{tabular}


4.14 Membentuk karya kerajinan dari bahan keras

Tabel 3. Tahapan Kegiatan model Project Based Learning (PjBL) dalam pembelajaran tematik menggunakan pendekatan saintifik

\begin{tabular}{|l|ll|}
\hline \multicolumn{1}{|c|}{ Kegiatan } & \multicolumn{2}{|c|}{ Tahapan Model } \\
\hline Kegiatan Awal & & \\
\hline Minggu Ke-1 & 1. & Penentuan pertanyaan mendasar \\
Kegiatan Inti & 2. & Mendesain perencanaan proyek \\
& 3. & Menyusun jadwal \\
\hline Minggu ke-2 & 1. & Memonitor peserta didik dan kemajuan proyek \\
& 2. & Menguji hasil \\
\hline Minggu Ke-3 & 1. & Menguji hasil \\
& 2. & Mengevaluasi pengalaman \\
\hline Kegiatan Penutup & & \\
\end{tabular}

\section{Instrumen penilaian sikap peduli lingkungan dan kreativitas bagi siswa SD}

Instrumen penilaian sikap peduli lingkungan dan kreativitas bagi siswa SD yang telah dikembangkan berupa lembar observasi dan angket penilaian kreativitas.

\section{PEMBAHASAN}

Penerapan kurikulum 2013, sistem pembelajarannya menggunakan pendekatan tematik integratif. Pembelajaran tematik integratif merupakan pendekatan pembelajaran yang mengintegrasikan berbagai kompetensi dari berbagai mata pelajaran ke dalam berbagai tema.Kelebihan pembelajaran tematik diantaranya: 1)Memberikan pengalaman yang menyenangkan dan kegiatan pembelajarannya sesuai dengan tingkat perkembangan anak, 2) Mengembangkan ketrampilan berpikir anak sesuai dengan permasalahan yang dihadapi, 3)Menumbuhkan ketrampilan sosial dalam bekerjasama, sehingga memiliki sikap toleransi (Kemendikbud, 2013). Pembelajaran tematik memberikan kemudahan bagi siswa dalam memahami konsep materi yang tergabung dalam tema serta dapat menumbuhkan semangat belajar, karena materi yang dipelajari merupakan materi kontekstual dan bermakna.

Penelitian ini memetakan tema, kompetensi dasar dan indikator pada kelas IV dan kelas V SD yang memuat sikap peduli lingkungan. Tema-tema yang memuat sikap peduli lingkungan di kelas IV yaitu :1)Tema
Selalu Berhemat Energi, 2) Peduli terhadap lingkungan hidup, 3) Berbagai Pekerjaan, 4) Indahnya negeriku, 5) Tempat tinggalku. Sedangkan untuk kelas V ada 4 tema yaitu : 1) Benda-benda di lingkungan sekitar, 2) Peristiwa dalam kehidupan, 3) Ekosistem, dan 4) Lingkungan sahabat kita. Tema berperan sebagai pemersatu pembelajaran yang memadukan mata pelajaran PKn, Bahasa Indonesia, IPA, IPS dan SBdP. Tema-tema tersebut berisi konsep-konsep pendidikan lingkungan hidup yang dapat menumbuhkan sikap peduli lingkungan Yaumi (2014) menyatakan bahwa "peduli lingkungan dipahami sebagai suatu sikap dan tindakan yang selalu berupaya mencegah kerusakan pada lingkungan alam di sekitarnya dan mengembangkan upaya-upaya untuk memperbaiki kerusakan alam yang sudah terjadi".

Penelitian ini mengembangkan model Project Based Learning (PjBL) dalam pembelajaran tematik menggunakan pendekatan saintifik. Pembelajaran tematik memiliki beberapa kelebihan sebagai berikut: (1) Memberikan pengalaman yang menyenangkan dan kegiatan belajar mengajar yang relevan dengan tingkat perkembangan dan kebutuhan anak. (2)Mengembangkan keterampilan berpikir anak sesuai dengan permasalahan yang dihadapi. (3) Menumbuhkan keterampilan sosial dalam bekerja sama, sehingga memiliki sikap toleransi, komunikasi dan tanggap terhadap gagasan orang lain, dalam arti respek terhadap gagasan orang lain. Dan (3) Menyajikan kegiatan yang bersifat 
pragmatis sesuai dengan permasalahan yang sering ditemui dalam lingkungan anak (Kemendikbud, 2013).

Dalam

pembelajaran

tematik

menggunakan pendekatan saintifik (scientific). Pendekatan Saintifik dalam Kemendikbud (2013) memiliki ciri-ciri yaitu, penonjolan dimensi pengamatan, penalaran, penemuan, pengabsahan dan penjelasan tentang suatu kebenaran. Sehingga, proses pembelajaran dengan menggunakan pendekatan scientific harus dipandu nilai-nilai, prinsip-prinsip atau kriteria ilmiah. Dalam proses pembelajaran guru harus mengedepankan kondisi siswa yang berperilaku ilmiah dengan

bersama-sama diajak mengamati, menanya, menalar, mencoba dan membentuk jejaring.

PjBL merupakan model pembelajaran yang menekankan pembelajaran yang berpusat pada siswa dalam suatu proyek (Thomas, 2000). Sedangkan menurut Sani (2014) model PjBL merupakan strategi belajar mengajar yang melibatkan siswa untuk mengerjakan sebuah proyek yang bermanfaat untuk menyelesaikan permasalahan masyarakat atau lingkungan. Berdasarkan pengertian tersebut di atas model PjBL sangat ideal dijadikan model untuk kegiatan pembelajaran yang mengubah sampah yang tak bernilai menjadi sebuah karya yang berharga. Siswa dilibatkan untuk menyusun proyek memanfaatkan sampah organik menjadi pupuk kompos dan sampah non organik menjadi karya kolase atau kerajinan tangan yang bernilai ekonomis.

Langkah-langkah model PjBL adalah sebagai berikut: (1) penentuan pertanyaan mendasar (start with the essential question), (2) mendesain perencanaan proyek (design a plan for the project), (3) menyusun jadwal (create a schedule), (4) memonitor siswa dan kemajuan proyek (monitor the students and the progress of the project), (5) menguji hasil (assess the outcome) dan (6) mengevaluasi pengalaman (evaluate the experience) (Kemendikbud, 2013).

Melalui pengenalan konsep PLH diharapkan dapat mengembangkan sikap peduli lingkungan siswa SD. Sikap Winarni (2012) merupakan salah satu unsur kepribadian yang harus dimiliki seseorang untuk menentukan tindakan dan bertingkah laku terhadap suatu objek yang disertai dengan perasaan, penerimaan atau penolakan. Sikap merupakan tanggapan psikologis seseorang terhadap objek tertentu baik berupa benda maupun kegiatan yang datang dari luar dirinya. Selanjutnya sikap peduli lingkungan merupakan sikap dan tindakan yang selalu berupaya mencegah kerusakan pada lingkungan alam di sekitarnya dan mengembangkan upayaupaya untuk memperbaiki kerusakan alam yang sudah terjadi

Sikap siswa terhadap sampah dapat kearah positif atau negatif. Jika siswa bersikap positif terhadap sampah maka siswa akan cenderung menyenangi sampah dan memandang sampah sebagai sesuatu yang berguna dan bernilai, sehingga diharapkan muncullah sikap peduli lingkungan pada diri siswa. Sikap peduli siswa akan sampah tersebut memicu tumbuhnya kreativitas dalam membuat karya yang bernilai ekonomis berbahan baku sampah. Sedangkan jika siswa bersikap negatif terhadap sampah maka siswa akan cenderung menjauhi, membenci dan tidak peduli terhadap sampah yang ada di sekitarnya.

\section{KESIMPULAN}

Kesimpulan dari penelitian ini adalah: (1) telah dihasilkan produk berupa pemetaan tema dan subtema untuk kelas IV dan kelas V, (2) telah dihasilkan produk berupa perangkat pembelajaran model Project Based Learning (PjBL) dalam pembelajaran tematik menggunakan pendekatan saintifik untuk mengembangkan sikap peduli lingkungan dan kreativitas bagi siswa SD untuk kelas IV dan kelas V SD dan (3) telah dihasilkan instrumen penilaian otentik untuk menilai sikap peduli lingkungan dan kreativitas siswa SD. 


\section{SARAN}

Hal yang disarankan dari penelitian ini untuk peneliti lain yang berminat meneliti sikap peduli lingkungan dan kreativias adalah untuk mengembangkan kembali perangkat pembelajaran berdasarkan potensi daerahnya masing-masing.

\section{REFERENSI}

Borg, W.R. dan M.D. Gall. 1983. Educational Research: An Introduction (4 ${ }^{\text {th }}$ edition) New York: Longman.
Hamzah, Syukri. 2013. Pendidikan Lingkungan. Bandung : Refika Aditama

Hardianti, Enyea Winanda. 2015. Sikap Peduli Lingkungan, Pengetahuan dan Keterampilan Membuat Kolase Menggunakan Model Project Based Learning (PjBL). Bengkulu: Skripsi Universitas Bengkulu

Kemendikbud. 2013. Bahan Pelatihan Kurikulum 2013. Jakarta: Pusbangprodik

Sani, Ridwan Abdullah.2014 Pembelajaran Saintifik untuk implementasi Kurikulum 2013. Jakarta: Bumi Aksara

Thomas, J. 2000. A Review of Research on Project Based Learning. California: Jurnal PjBL

Winarni, Endang, W. 2012. Inovasi Dalam Pembelajaran IPA. Bengkulu: Unit Penerbitan FKIP UNIB

Yaumi, Muhammad. 2014. Pendidikan Karajter Landasan, Pilar \& Implementasi. Jakarta: Predandamedia

Group 